\title{
DEFINING INTEGRATED LEARNING: PERSPECTIVES FROM ALUMNI OF THE CHRISTIAN UNIVERSITY IN THE DEMOCRATIC REPUBLIC OF THE CONGO (DRC)
}

\section{Author: \\ K. H. Bunduki \\ L. G. Higgs ${ }^{2}$}

\section{Affiliation:}

${ }^{1}$ Université Chrétienne Bilingue du Congo - UCBC (Christian Bilingual University of the Congo), Faculty of Theology

${ }^{2}$ College of Education, Department Education Foundations, University of South Africa

\section{Correspondence to:}

B. K. H.Bunduki

Email:

bhonorekwani@gmail.com

\section{Correspondence to:}

L. G. Higgss

Email:

higgslg@unisa.ac.za

Dates:

31 Oct 2016

How to cite this article: Bunduki, B. K. H \& Higgs, L. G., 2016. "Defining integrated learning: perspectives from alumni of the christian university in the democratic republic of the congo (drc)". KOERS - Bulletin for Christian Scholarship, 81(2). Available at: http://dx.doi.org/10.19108/ koers.81.2. 2255

\section{Copyright:}

(C) 2016. The Author(s).

Published under the Creative Commons Atribution License.
This article examines the various perspectives of alumni from the Christian Bilingual University of the Congo $(\mathrm{UCBC}$ ) on the topic of integrated learning. In this article, both an understanding and a definition of the concept of integrated learning are achieved by analysing data obtained from the twelve alumni. The tool used was semi-structured interviews. Five themes emerged as part of the definition of the concept. Firstly, integrated learning is a holistic education. Secondly, it is described as a complete education because it deals with all aspects of learners' lives. Thirdly, integrated learning emphasises theory and practice and, fourthly, it prepares learners to be people of significance in their nation. Fifthly and lastly, it is a learner-centred process focused on building the inner person. These perspectives on integrated learning are judged to be important for Christian universities and higher education practitioners who are all invited to design ways of holistically involving learners in learning.

KEYWORDS: Alumni, Christian university, Complete education, Holistic education, Integrated learning, Theory and practice

Hierdie artikel ondersoek die verskillende perspektiewe van alumni van die Christian Bilingual University of the Congo (UCBC) oor die onderwerp van geïntegreerde leer. In hierdie artikel word sowel ' $n$ begrip as ' $n$ omskrywing van die konsep van geïntegreerde leer bewerkstellig deur data wat van die twaalf alumni verkry is te ontleed. Die metode wat gebruik is, is halfgestruktureerde onderhoude. Vyf temas kan onderskei word as deel van die omskrywing van die konsep. Eerstens is geïntegreerde leer' $n$ holistiese opvoeding. Tweedens word dit as ' $n$ volledige opvoeding beskryf omdat dit oor alle aspekte van leerders se lewens handel. Derdens beklemtoon geïntegreerde leer beide teorie en die praktyk, en vierdens berei dit leerders voor om van betekenis te wees in hul nasie. Vyfdens en laastens is dit' $n$ leerdergesentreerde proses wat daarop fokus om die innerlike persoon op te bou. Hierdie perspektiewe oor geïntegreerde leer word as belangrik beskou vir Christen-universiteite en hoëronderwyspraktisyns, wat almal uitgenooi word om met wyses vorendag te kom om leerders holisties by leer te betrek.

SLEUTELWOORDE: Alumni, Christen-universiteit, Volledige opvoeding, Holistiese opvoeding, Geïntegreerde leer, Teorie en praktyk 


\section{INTRODUCTION}

Education plays an important role in building lives and communities. In its 1998 report, UNESCO (1998:13) emphasises education as an indispensable asset for humanity to attain ideals that individuals and communities all over the world long for: peace, freedom and social justice. Half a century ago, Broudy (1961:8) noted that through formal learning, education gives shape to learners' personal experiences and releases the potential in learners that allows them to flourish; to conduct happy, contented, meaningful lives; and to edify humanity. Rather than being simple professionals, learners with fashioned lives become people who carry the fate of communities and nations. Such people contribute to the promotion and advancement of a culture of peace, the protection of the environment, and the fostering of social justice. They are not only able to respond to the basic learning-related needs of their fellow citizens but are shaped into active agents of development and change in their contexts (Robbins in Clark 1988:xii).

Societal plights, as observed in the DRC and throughout the world, result from people being in a state of crisis, and for Turnbull (2011:16) and Jan Vasina (in Afolayan 2007:xi), writing from the political perspective, the solution to Africa's many plights will only come through education (specifically higher education) as the pinnacle of the educational system. What is the type of education that can provide in all social needs, tackle philosophical, ethical and practical issues that beset society and that can be conducive to effecting visible change in any society? It is certainly not the banking-type education, marked by rote memorisation and theory, which Paulo Freire (2010) so ably refuted. Indeed, such education acts as an inhibitor of opinions, critical thinking, judgement and perspective. It contributes to the loss of the consciousness of collective welfare. However, education that uplifts the person in the learner - mind, heart, soul and body - has the potential to holistically prepare students to work towards the improvement of living conditions in the community. The aim of this article is to gain a deeper understanding of such education (here labelled integrated learning), by examining the lived experiences of alumni from the Christian bilingual university in the DRC.

\section{LITERATURE REVIEW}

\section{Defining integrated learning: perspectives}

In recent decades, a number of scholars have written about integrated learning. Examining complex qualifications brought about by the expansion of information technology, industrialisation and the computerisation of services, Laur-Ernst (1999) argues that learning should involve certain aspects of the learner's total being. Sharply opposed to traditional education with its dissected view of the learner's being, integrated learning involves the cognitive, emotional and psycho-motor facets of the student participating in the learning activity. This holistic approach of all learning activities by educators stands at the centre of English's preoccupation (2003:82), which contends that educators should look constantly at the whole of their practices without dissecting each piece, in order to prepare learners as whole beings.
As a result, learners will learn to involve, though not necessarily to the same extent, all facets of their beings in every action and situation that they encounter.

Alexandrov and Ramirez-Velarde (2013:147) bring a different perspective to integrated learning. In their view, integrated learning is a process built on interactive learning in a social setting. They root their perspective in the natural learning cycle described by David Kolb (2001). This cycle evolves in four interchangeable movements: concrete experience, reflective observation, abstract hypothesis and active testing. The role of the facilitator in this process is to create a setting in which students can freely and naturally move and act to develop critical thinking, innovative actions and emancipatory will through interactions in social settings, as in the context of real life. Learners thus learn to open up to collaborative work.

In the United States of America (USA), major Christian perspectives on integrated learning were first voiced in the 1980s. Central to these perspectives was the focus on the integration of faith and learning. In his book, The idea of a Christian college, Holmes (1987:77) notes that a Christian university is, basically and firstly, a community of Christians which ensures that all the university's undertakings and actions (whether social, intellectual or cultural) are led by Christian values. He adds that in such a context, learning is perceived holistically, as an educational act that approaches life as a whole and from a purely Christian perspective. Basically a situation is crafted to help students develop virtue and relate everything they do and are involved in (curricular and extracurricular activities) to their faith which will shape their worldview and underlie all that they think and do.

Building on Holmes' argumentation, Hasker (1992:234) describes the integration of faith and learning as "a scholarly project whose goal is to develop integral relationships which exist between the Christian and human knowledge, particularly as expressed in the various academic disciplines". However, clarity is needed here: 'faith', characteristic of the Christian life and 'knowledge' are used in a rather broad sense of belief in one God, Creator of all things through his only Son Jesus Christ. A more specific understanding of faith, though not within the scope of this work, is found in the Holy Scriptures where faith is defined as "the assurance of things hoped for, the conviction of things not seen" (Hebrews 11:1, Revised Standard Version). The focus in this article is on the cognitive content of faith; that is, how knowledgeable man is about God as Creator and Source of all things including science, learning and scholarship - through which man tries to understand, discover and disseminate knowledge on new realities. From this perspective, the integration of faith and learning accounts for the global relationships that exist between faith content and knowledge in any subject or discipline that is taught. The thread that connects learning to faith, in this case, is the general biblical narrative and/or the biblical worldview which for a number of Christian scholars is foundational to any attempt to integrate faith and learning in Christian universities (Holmes 1987:57; VanZanten 2011:173 \& Glanzer 2008:45). 
However, Glanzer (2008:42) suggests discarding the 'faith and learning integration' language from Christian universities for the evident reason of the thinking habit that it fosters; he is not against the 'integration model' itself. He advocates, instead, the use of 'creation and redemption of scholarship' to align with the theological mission of Christian scholars, thus retaining and expanding a basic integration paradigm. While his suggestion is justified, we would prefer the alternative language of 'faithshaped learning' that deals with Glanzer's concern and has the advantage of clearly positioning faith, properly defined, as the central factor that informs, guides and builds every form of thinking in Christian scholarship.

Academically, this article is aligned to the definition of Mothata, Lemmer, Mda and Pretorius (2002:87). These authors define integrated learning as a new approach to education that implies a view of learning where rigid division between academic and applied; theory and practice; knowledge and skills; head and hand are rejected. Instead, the learner is approached as a whole system and every effort should be made to uncompromisingly reject compartmentalisation in his or her being during the learning process.

\section{Integration: compartmentalisation and dualisms}

For Van der Walt (2002:209) compartmentalisation is characteristic of higher education institutions that fail to even consider incorporating integration in their educational practice. Instead, these institutions train the learner as a set of separate sub-systems with boundaries between facets of life according to the context of time and space. This compartmentalisation logic, also prevalent in the 'faith and learning integration' language, makes space for dichotomist dualisms. In his examination of these dualisms, Esqueda (2014) cites fifteen sets identified as part of the compartmentalisation paradigm within Western Christianity. Esqueda reveals four metaphysical dualisms (sacred/secular, eternal/temporal, spirit/ matter, heaven/earth); two anthropological dualisms (soul/body, spirit/flesh); four epistemic dualisms (faith/science, fact/value, head/heart, and freedom/authority); and five ethical-political dualisms (private/public, belief/behaviour, individual/community, church/state, Christ/culture).

Most of these dualisms are also visible within African and Congolese educational practices, exported from the West. The most prevalent in higher education in the DRC (public or Christian) are faith/science, head/heart, soul/body, individual/ community, belief/behaviour, and sacred/secular. In the dualisms faith/science and head/heart, the focus is on giving learners science in order to develop their reasoning ability; they are given very little opportunity to nurture faith and develop a virtuous character. Early universities in the DRC, most of which were established by Christian churches ${ }^{1}$ attempted to emphasise Christian values. However, all these universities felt

$1 \quad$ The University of Lovanium (currently the University of Kinshasa) and the Free University of Congo (currently the University of Kisangani) were both established as Christian universities - the former in 1954 by the Catholic Congregation of Jesuits and the latter in 1963 by protestant missionaries. the effects of secularisation and specialisation. As a result, they ended up relegating character formation to the back row and, of course, all became secular institutions (Devisch 2007:32; Matangila 2003:18-19 \& Malengreau 2008:11).

Regarding the soul/body dualism in DRC higher education: training the body for work and in the work ethic is simply history today. In primary and secondary school, up to the late 1980s, manual work (as part of training through service) was an important component of the curriculum. However, from the 1990s onwards, this progressively lost ground and today most pupils prefer to pay something to the teacher or invigilator to avoid doing manual work.

Concerning the individual/community dualism: for many in Congolese society, the focus is increasingly on individual gain rather than community welfare. Lastly, in Congolese society, the trend is for people to behave according to what they want, rather than by focusing on what is needed and important for everybody. Thus, people's behaviour varies according to time and context and very few live what they claim to believe. In fact, a general confusion prevails among both believers and nonbelievers. A Christian gospel singer has aptly portrayed this fact in one of his songs, in which he expresses his desire to see his Christian brothers and sisters live upright lives ${ }^{2}$. Integrated learning, as examined here, attempts to remedy this situation.

The situation described in the lines above reflect a fact that Carpenter (2012:18) points out as a problem common to new Christian universities on the African continent, where learners search for 'personal good against public good', 'information against formation' and 'skills and techniques against perspective and judgement'. This problem largely contributes to a crisis in people, a crisis which negatively affects communities as a whole. But integrated learning, which fashions souls and hearts, as well as the mind, can help redeem the situation and bring about much-needed change.

\section{Integrated learning in the DRC educational system}

Very little has been written about integrated learning in the DRC educational system (primary, secondary and higher education). This article contributes a Congolese perspective on the concept by examining the lived experiences of students trained in an integrated learning context. Professor N'Sial (2007) is among the first Congolese scholars to recognise the need for integrated learning. In his book, Former pour transformer, he reports that between 1971 and 1981 the National University of Zaire $^{3} /$ UNAZA issued more than 35000 diplomas. Today the

2 Patrice Ngoy Musoko, President of the Association of Christian Gospel Singers in the DRC, sang in his album Confusion: "J'ai cherché le monde, je l'ai trouvé dans l'Eglise, et l'Eglise je l'ai trouvé dans le monde. CONFUSION». (I sought the world and I found it in the church, and the church I found it in the world. It's all CONFUSION, was his conclusion.) Upon its accession to independence the country was called 'The 
figure has not simply tripled, but has increased exponentially ${ }^{4}$, as has the number of higher education institutions. At Expo $2014^{5}$, statistics revealed that the number of higher education institutions in DRC (Zaire) had increased - there were now 475 public and more than 500 private institutions.

For N'Sial (2007:96) one question remains: why don't these graduates positively influence the country and help it to progress? He attributes the situation to three problems in educational practice: teacher-centredness, a lack of integrated learning, and training programmes that simply do not encourage development. As far as teacher-centredness is concerned, teachers control and own the educational activity and, indeed, it is from this that they draw their social status and prestige. N'Sial holds teachers responsible for the deterioration of the situation in the country. He concludes by reminding these teachers that the society that had graciously given their profession respect and social status would one day hold them responsible for the ongoing evils in Congolese society.

Furthermore, teacher-centredness fosters a strong academic divide between teachers and learners and inhibits interactive learning. Teacher-centredness is a tributary of the Belgian paternalistic legacy passed on through colonisation, and the traditional social stratification scheme also contributes to its perpetration. In Congolese society, the elderly, and in some cases the privileged, is assumed to possess wisdom and has the last say in everything, even in instructional matters. Attitudes resultant from such social scheme inhibit initiative and critical thinking in learners and they favour teacher-centredness.

Lack of integration in Congolese education is characterised by three realities. First, emphasis is placed on filling learners' minds with information and knowledge. Learners acquire the ability to think rationally but they lack the wisdom of the heart as part of character formation developed through faithrelated activities in Christian universities. Secondly, science is lifted above faith. Learners are denied the opportunity to transcend the rational and enter the realm of the spiritual/faith where virtue is cultivated and where true meaning of life is

Democratic Republic of the Congo'. In 1971, President Mobutu initiated a vast campaign of reverting to authenticity and he named the country, and with it, the currency and the river, 'Zaire'. In 1997, when Laurent-Désiré Kabila ousted Mobutu from power, he changed the country's name, and with it the currency and the name of the river, back to 'Congo'.

According to an evaluation of scenarios based on impact on coverage indicators, in the period of 2009-2022 the DRC would produce over 1 million post-graduates if there were to be a rationalisation of the ratio for non-teaching vs. teaching staff (source: World Bank 2005). discovered. Thirdly, service is geared towards personal benefit, easy gain and egotistical ambitions. Thus, there is a demise of servanthood and learners are robbed of the opportunity to have good models to emulate.

The educational curriculum in the DRC is oriented towards academic subjects and theories. It essentially focuses on training the mind and leaves very little space to develop other aspects of the learner's being. The understanding that learning should only be about academics and completing the learning load in theory is deeply anchored in learners' minds. In fact, one alumna from UCBC phrased the fact in these words: "I came here just to learn. I came here for academics. Why all these things? [Referring to service-learning and work program]". Adapting to integrated learning as a new approach to training learners can be demanding in the beginning but with time learners adjust to the system. An alumna explained it as follows: "But when with time I really found it very important, I liked it... I can say that studying at UCBC is enjoyable and challenging; challenging especially for new students." Even though integrated learning can be demanding and hard to adapt to, it is an experience worthy of being tried. In fact, it is through trying new ways and ideas that life is enriched.

This article has two purposes. First it seeks to gain a deeper understanding of integrated learning and what is integrated with what. It also serves as a call to educators, in the DRC and in the world, to embrace and try integrated learning when training learners for purposes of effecting change in communities.

\section{UCBC: brief overview of educational practice}

UCBC is a chartered Christian university established in 2007 in Beni, North-Kivu Province, DRC. Its commitment is to train prospective leaders who display Christ-like character, excellence and servanthood. As noted earlier, the higher education curriculum in the DRC is oriented towards academic subjects, theory and memorisation. In contrast, UCBC strives to provide holistic education that blends theory and practice through the combination of academics, service-learning and work programmes. The service-learning and work programme are blended in the curriculum as practical training components.

Service-learning is pedagogy and an educational philosophy that takes learners from the classroom to the community. As pedagogy, service-learning provides learners with collaborative learning opportunities and peer teaching for increased retention. As philosophy, it leads learners to a reflection on humanness, life conditions and how to respond to the needs of people. Service-learning develops servant leadership in learners and it opens their hearts to transformation. The work programme focuses on service in the community. Learners weekly participate in three types of services: campus care, community action and creation care. The work programme involves students, teachers and staff; it contributes to tearing down the academic divide among the campus community members and it develops a work ethic, team work skills and servanthood in learners.

\section{RESEARCH METHOD}


The design for this study was qualitative with a phenomenological method. Thoughts and perspectives of participants were sought from lived experiences through open-ended, in-depth interviews (McMillan \& Schumacher 1996:31; Harwell 2011:148), and a study fundamentally concerned with the common meaning, structure and essence of the lived experience of several individuals is seen as being phenomenological (Patton 2002:104; Creswell 2013:76). One question, with many promptings, was asked to each participant to seek his/her perspectives of lived experiences on integrated learning: What is your understanding of integrated learning at UCBC?

Twelve participants were purposefully selected for the study following the criteria below:

1. be an alumna/nus from one of UCBC's four faculties

2. having graduated in the academic year 2010-2011 or 2011-2012

3. be working in the community during the time of study

UCBC has four faculties (Theology, Economics, Communication and Applied Sciences), and participants were selected to represent a variation in sample across the faculties and in gender. Three participants were selected from each faculty. Female representations from faculties were as follows: two from Communication, one from Economics and one from Applied Sciences. No female alumnae met the selection criteria in the faculty of Theology.

Permission to carry out the study was obtained from the university management and a letter of consent was duly sent to participants, stating all ethical considerations, including confidentiality, anonymity and the right to withdraw at any stage. After consent to participate had been obtained, each participant was interviewed at their time and place of convenience.

Eight participants chose to be interviewed in French while the rest took the interview in English. Interviews lasted twenty-five minutes on average; they were all tape-recorded, transcribed verbatim and reviewed by participants. All transcripts in French were then translated into English prior to analysis.

Data analysis was thematic and involved horisontalisation, which consisted of going through all transcripts, highlighting significant statements and discarding irrelevant statements (Moustakas 1994; Creswell 2013:82). After that, clusters of meaning that had been developed from the significant statements were grouped under emerging themes. This grouping was done for the purpose of writing a structural and composite description, presenting the definitions and essence of the integrated learning phenomenon.

\section{RESEARCH FINDINGS}

The analysis of the twelve verbatim transcripts yielded five major themes that define integrated learning as: holistic and complete education; learning that combines theory and practice, learner-centred learning, learning that focuses on the inner building of learners, and learning that prepares learners to make an important contribution to their society.

\section{Holistic and complete education}

Alumni defined integrated learning as holistic and complete training. They described it as an education that affects more than the intellect and touches the body, the mind, the soul and the heart. One participant commented that "integrated learning means involving the mind, the body and the soul. The mind because you have academic learning, the body because you have manual work, the soul because you have spiritual training and compassion. Insisting more on the complete nature of the training, another participant said: "I can say that education that UCBC offers is really exceptional because it is not an education in half. I can say that it is complete education because we were trained not only in relation to courses ... but we also received spiritual education, as well as moral education..."

In previous research Laur-Ernst (1999), English (2003:82) and particularly, Mothata et al. (2002:87) indicate that integrated learning should reject rigid division between the academic and applied, theory and practice, knowledge and skills, head and hand. Learners should be considered as holistic systems. These scholars particularly emphasise the dualism 'head/hand' and 'theory/practice'. Results of this study uncover the dualism heart/soul to emphasise character formation received through the overall Christian spiritual dimension in training at UCBC.

\section{Learning that combines theory and practice}

UCBC alumni also experienced integrated learning as an education that intentionally combines theory and practice. Learning at UCBC was described as 'more practical training' and as a process that helps learners to combine both serving and studies as a preparation for professional life. This is a rather rare practice in education in the DRC. The expectation at universities, one participant commented, is "to have more of theory".

So, in the early days of their first year at UCBC, most students experience the combination of theory and practice as frustrating, 'strange', something they weren't prepared for and a waste of time. One participant noted the fact in these words: "I came here just to learn. I came here for academics. Why all these things? [Referring to the practical side of the curriculum at UCBC - service-learning and work programme.]" Another participant added: "Now, once we mixed theory and practice, sometimes it seemed to be strange for us because we weren't prepared to do that ... at a point we thought it was just a wasting of time."

Findings reveal that integrated learning was perceived as a new approach to education, a practice that does not exist in other universities. One participant stated it this way: "In other institutions what they do is only giving academics. They focus on that and it's only that. So, RARE are the institutions where they also 
give you the opportunity to develop other parts of yourself."

N'sial (2007) has identified teacher-centredness and lack of integration as part of the problems in DRC education. Lecturers tend to focus on completing required teaching loads through intensive teaching. As a matter of fact, learners are often overwhelmed by theoretical content given in a rush as lecturers, particularly adjunct faculty, try to accomplish a lot (often four or even five courses) in a very short period (three to four weeks) before they move to the next institution. Learners have gradually come to believe that this is normal teaching and many have the expectation that all teaching should follow the same pattern. On the other hand, most hosting institutions also condone the practice - as it allows them to shorten visiting lecturers' stay and helps to reduce expenses (housing, food and transportation to and from school).

However, experiences of UCBC alumni reveal that allocating enough time to theory and practice allows learners to engage the community and prepare themselves for professional life during their training, through meaningful services in and with the community. One of the participants recognised that the training they received at UCBC "...was an education that was already preparing us [them] for professional life."

Moreover, all participants felt that their self-esteem was boosted and they realised that they were special. One of the participants serving as Managing Director in an import and export company explained: "The moral education that we received at UCBC and the academic training that we got; there is also the work ethic that we learned. All these things, put together, they give us a sort of experience that others don't have. It is something special. So, you realise that you are special. You don't behave like others."

Findings also revealed many other advantages learners reaped through integrated learning, such as the removal of all sorts of complexes and hearts set on service - as conveyed by a participant: "it [training through service] took away that inferiority or superiority complex... I really like to serve people in the community... when I realise I served someone, I really sleep at peace." Furthermore, students learned to humbly face life, give the best of themselves and live in harmony with all. Commenting on this point, an alumnus stated: "I remember we used to have groups and in each group there was a staff member who would lead us, but there were also students. If you work with, for example, a teacher... if you are in charge of taking attendance at the end, he will also come to you... There was an 'atmosphere' which allowed everyone to express their thoughts, to give the best of themselves in everything they did."

Finally, training through work program was experienced as not only important but also as a preparation for future life. One participant noted: "you feel that it [work program] is something which prepares you for future life ... you feel that if your refuse to do it, it is a bad service you render to yourself ... it is a part of your life that you want to erase." Ownership of all components of integrated learning was demonstrated and a conversion of educational culture initiated.

\section{Learner-centred learning}

Findings revealed that learners experienced learnercentredness and friendly interactions among members of the campus community: learners (all levels), teachers and staff, and the neighbouring community. Teachers and staff were described and referred to as 'role models', 'facilitators', 'mentors' and 'accompagnateur' who were always there for students and stood beside them in class, in the work programme, in servicelearning projects, in spiritual activities, in extracurricular activities and in life in general.

Accessibility to staff, teachers and the school leadership was described as denoting a family-like environment which contributed to the nourishing of casual and free interactions not common in other higher education institutions. A participant thus explained that "...in other institutions you can hardly find someone for instance with a school authority just in a casual way. No, that doesn't happen. But here at UCBC that was the case. So, I come to you [teacher/staff] and I feel that I am in front of my dad. I share my problem with my dad ... When I share with everybody, I have solutions to my problems as if I were in my family." However, even if there were free interactions among the school community members, participants noted a prevailing notion of dignity because "even if there was general friendship, there was respect; mutual respect."

Interactions among peers also contributed to learning as well as to personal fulfilment. An alumnus serving in a bank noted this: "Apart from studies, you can also learn from other friends, other students..." Telling his personal story, another participant said: "When I arrived at UCBC, I had many weaknesses. For example, I did not know that I could be able to stand in front of people and be able to do something on my own. So, I felt useless in front of everybody... it was in a peer group that I had my first experience of sharing my personal life with others, expressing myself in front of people..."

Alexandrov and Ramirez-Velarde (2013) recognise interactive learning in social settings as a contributor to learnercentredness. Participants identified several social settings at UCBC designed to draw members of the campus community closer one to another. The most important of those settings are classrooms, mentoring groups, peer groups, houses, Bible study groups, the university choir, family talks, exposés, the student body, student organisations, sports teams, clubs (movie, English), spaces under mango trees, etc. In the centre of all these activities and settings are students, the existential raison d'être for every university.

\section{Learning that focuses on the inner building of learners}

Four emerging patterns were experienced and described as part of the inner building of learners: strengthened spiritual lives (spiritual growth), empowerment (selfconfidence), development of servanthood with a strong sense of accountability, and distinctiveness in community. Spiritual growth was experienced as resulting from three things: involvement in spiritual activities, effectively using God-given gifts, and personally surrendering to the Holy Spirit. 
As a Christian university, UCBC organises spiritual activities for all members of the campus community through the chaplaincy office. These spiritual activities include two weekly chapel sessions (the only mandatory activity for all UCBC community members), Bible studies, reflection day (at the end of the month) and special chapel sessions. Spiritual activities foster Christ-like character in learners and prepare them to be able to prioritise service and collective welfare as the higher good that leads to greatness. Learners are thus prepared to make wise and virtuous, but autonomous judgements in everyday life.

Character development and empowerment were concomitantly experienced as the result of spiritual activities and knowledge acquired in class. Participants spontaneously expressed empowerment through phrases such as 'I can...', 'I am confident', 'you are able', 'you can defend what you are doing', 'you have the capacity to find your way, to be determined, to defend yourself in front of facts and also better do what you can do'. In more elaborate terms, a participant explained this: "When I arrived at UCBC, I had many weaknesses ... I managed to get the minimum and I am able today up to a certain level to do this work or that work related to my field of training. I am confident in that."

Findings revealed that integrated learning also contributed to developing a heart for service with a sense of accountability in learners. As directly related to servanthood, participants' attitudes and actions demonstrated humility in varied circumstances. For instance, in the workplace they did not feel confined to positions and fancy titles but they exhibited readiness to serve in any position and anywhere. Insisting on the importance of servanthood in society, one participant noted, "Knowledge itself cannot develop a community but there is a need for people who are ready to serve because both in leadership and in community, service is needed."

The findings of the study have shown that besides academic competence, integrated learning allows learners to develop virtue through spiritual/faith-related activities and faithshaped learning; and this constitutes the core mission of Christian universities - as recognised by Holmes (1987) and VanZanten (2011). Upon completion of their training at UCBC, participants displayed responsible ways of behaving emulated by many in their respective communities, including students from other universities. Students thus became leaders of the change through being role models in the community.

\section{Learning that prepares learners to play an important role in their nation}

Education is an indispensable asset for humanity to attain ideals that individuals and communities all over the world long for (UNESCO 1998:13). Added to that, Broudy (1961:8) stated that education trains people through fashioning their personal experiences to edify humanity - by being agents and advocates of peace, freedom and social justice.

Findings of this study concur with the thoughts of Broudy and UNESCO - as participants felt empowered by integrated learning at UCBC to be people of value to the nation. Most participants recognised that emphasis in their training was not simply on imparting science but preparing them to play a role in nation-building. In varied ways participants echoed the query foregrounded by N'Sial (2007) about why graduates are not positively influencing the DR Congo towards progress. One alumna insinuated the fact when she said, "the more they [students] study, the more they become mischievous." However, she made a just appreciation of integrated learning as a "holistic approach which makes the student become perfect at all levels."

Integrated learning at $\mathrm{UCBC}$ was experienced as a response to N'Sial's (2007) concern and a preparation of learners for nation building. A participant hence commented that "[a]t UCBC they don't only see the science ... So, the problem is not only to communicate science but most importantly, how can a student behave to become important for his country..." When learners are holistically prepared to be "solution bringers" fashioned to edify their nation and humanity, progress is just around the corner.

\section{The essence of integrated learning}

The understanding of integrated learning as holistic and complete education brings a contrasting alternative to education in most higher education institutions in the DRC perceived as being teacher-centred, focused on training learners intellectually and basically in theory and memorisation. In brief, education in the DRC is of the banking-type and it focuses learners' minds on knowledge for its own sake and for personal gain. Integrated learning, however, directs learners' volitional longings towards dependence on God, towards the development of an upright character and towards a spirit of service. It liberates learners from various fears, doubts and uncertainties (fear to stand boldly to serve in humility, fear of an uncertain future in a country with multiple plights, fear of failing to reach personal achievement, and for young ladies, and fear induced by a prevalent complex of inferiority in a society where men are given higher status than women). One alumna who has had a successful career in a gender equity promotion project and who is now a fellow of McCain Institute's Next Generation Leaders stated that "UCBC taught me how to do the best and be the best I can become."

Integrated learning empowers not only young ladies but all students - intellectually, spiritually, socially, morally and ethically - to thrive at their full potential. Besides, it tears down the academic divide between students and teaching and non-teaching staff, and nourishes healthy interactions in the learning community. Learners develop character, confidence, servanthood and social responsibility - all qualities which position them to be role models and change leaders in their communities and to bring hope to their nation.

\section{LIMITATIONS}

The purpose of this article was to gain a deeper understanding of integrated learning through accounts of alumni from a Christian university. A qualitative research methodology inherently imposes some limitations. Participants in this research came from only one Christian university, viz. UCBC. This means that results cannot be generalised and extrapolated to other Christian universities. However, other universities 
may find value in the findings of the study as they reflect on educational practices in their own institutions. Use of language was also a potential limitation, which was overcome by letting participants choose the language of interview between English and French. Participants in this research were all former UCBC students, so perspectives of teaching and non-teaching staff were not accounted for in the investigation.

\section{CONCLUSION}

In conclusion, integrated learning nurtures the heart, soul, body and mind and casts hope for the transformation of communities. Findings in this study have shown that integrated learning, a holistic education which combines theory and practice, has contributed to empower UCBC alumni to become transformed citizens and solution bringers in their communities.

The results of the study have addressed N'Sial's (2007) concern to see integrated learning implemented in DRC higher education and the challenge of new Christian universities on the African continent, as aptly articulated by Carpenter (2012). The learning experience of the alumni at UCBC was a joyful experience of acquiring perspective and judgement besides skills and techniques learnt for professional careers. Integrated learning has proven to be capable of allowing learners to experience delight in theoretical as well as practical education - pursuing formation and not mere information. It has also proven to be capable of redirecting learners' minds from the pursuit of private gain back to seeking the good of the community and of the nation.

The experience of UCBC is innovative and it stands in contrast to education in most higher education institutions in the DRC from many perspectives: learner-centredness, building the inner person, having a focus on both theory and practice, education through service and work; in brief, holistic and complete education. UCBC's experience in integrated learning initiates a culture conversion in higher education in the country. One could only hope for the experience to be duplicated in the country, on the continent and more widely in the (highly secularized) world.

Though results from a qualitative research project such as this cannot be generalised, this study offers a number of recommendations. First, leadership in Christian universities should be intentional in planning to address students holistically. It is important to equip the learner intellectually, but also physically, emotionally, socially and ethically, in theory and practice. When they are equipped in this way, learners become responsible citizens committed to collective welfare and personal achievement. This same recommendation could be of value to all practitioners in the realm of higher education. Secondly, perspectives of teaching and non-teaching staff, as well as those of parents, as social partners of universities, are an area for further research. For a broader and more complete understanding, investigating the practice of integrated learning in non-Christian universities would be another field for further research - especially in view of the fact that in a secularizing world an explicit Christian approach and worldview might be inimical to education planners, even though the values and practices inculcated by a Christian education and a non-Christian education might have similarities. 


\section{REFERENCES}

Afoláyan, M.O. 2007. Higher Education in Postcolonial Africa. Paradigms of Development, Decline and Dilemmas. Trenton, NJ 08607, Asmara, ERITREA: Africa World Press, Inc.

Alexandrov, N.S. \& Ramirez-Velarde, R.V. 2013. The Integrated Learning Process, Metacognition, and Collaborative Learning. In Technological Advances in Interactive Collaborative Learning, edited by Alexandrov, N.S., Ramirez-Velarde \& Alexandrov, V. Boca Raton: CRC Press.

Broudy, H.S. 1961. Building a Philosophy of Education. 2nd Edition. Englewood Cliffs, N.J.: Prentice-Hall, INC.

Carpenter, J. 2012. New Christian Universities and the Conversion of Cultures. Evangelical Review of Theology, 36(1):14-30.

Carpenter, J. 2014. Introduction: Christian Universities and the Global Expansion of Higher Education. In J. Carpenter, P.L. Glanzer \& N.S. Lantinga (Eds.), Christian Higher Education: A Global Reconnaissance. Grand Rapids, MI: Eerdmans.

Clark, G.H. 1988. A Christian Philosophy of Education. 2nd revised edition. Maryland, USA: The Trinity Foundation.

Creswell, J.W. 2013. Qualitative Inquiry \& Research Design: Choosing Among Five Approaches. Los Angeles, London, New Delhi, Singapore, Washington DC: SAGE.

Devisch, R. 2007. The University of Kinshasa: From Lovanium to Unikin. In Higher Education in Postcolonial Africa. Paradigms of Development, Decline and Dilemmas. Edited by Afoláyan, M.O. Trenton, NJ 08607, Asmara, ERITREA: Africa World Press, Inc.

English, L.M. 2003. An appreciative inquiry into spiritual values of Christian Higher Education. Christian Higher Education, 2(1): 71-90.

Esqueda, J.O. 2014. Biblical Worldview: The Christian Higher Education Foundation for Learning. Christian Higher Education, 13(2): 91-100.

Freire, P. 2010. Pedagogy of the Oppressed. New York: Continuum.

Glanzer, P.L. 2008. Why We Should Discard "the Integration of Faith and Learning": Rearticulating the Mission of the Christian Scholar. Journal of Education and Christian Belief, 12(1): 41-51.

Harwell, R.H. 2011. Research Design in Qualitative/Quantitative/Mixed Methods. In The SAGE Handbook for Research in Education. 2nd Edition edited by Conrad, C.F. \& Serlin, R.C. Los Angeles/London/New Delhi/Singapore/Washington DC: SAGE.

Hasker, W. 1992. Faith-learning integration: An overview. Christian Scholars' Review, 21(3): 234-248.

Holmes, A.F. 1987. The Idea of a Christian College. Grand Rapids, Michigan: Wm. B. Eerdmans Publishing Co.

Kolb, A. \& Kolb, D.A. 2001. Experiential Learning Theory Bibliography 1971-2001. Boston, MA: McBer \& Co.

Laur-Ernst, U. 1999. Integrated Learning of Complex Qualifications. In Bridging the Skills Gap between Work and Education. Edited by Wim J. Nijhoff \& Jittie Brandsma. Dordrecht; Boston: Kluwer Academic Publishers.

Malengreau, G. 2008. L'Université Lovanium. Des origines lointaines à 1960. Kinshasa: Editions Universitaires Africaines.

Matangila, M.L. 2003. L'Enseignement Universitaire et Supérieur au Congo-Kinshasa: Défis et Ethique. Paris/Kinshasa: L'Harmattan.

McMillan, J.H. \& Schumacher, S. 1996. Research in Education: Evidence-Based Inquiry. Boston: Pearson.
Mothata, S.; Lemmer, E.; Mda, T. \& Pretorius, F. 2000. A Dictionary of South African Education and Training. Johannesburg, London, Sydney, Auckland: Hodder \& Stoughton.

Moustakas, C. 1994. Phenomenological research methods. Thousand Oaks, C.A.: Sage.

N'Sial, S. C. 2007. Former pour Transformer [To Train in order to Transform]. Kinshasa: Edition de la C.P.E.

Patton, M.Q. 2002. Qualitative Research and Evaluation Methods. (3rd Edition). Thousand Oaks, CA: SAGE.

Turnbull, K. 2011. Discipling Africa Through Higher Education: a proposal for an African Christian University. Mission Frontiers (November-December): 16-18.

UNESCO. 1998. Learning: The Treasure Within. Report to UNESCO of the International Commission on Education for the Twenty-first Century. Paris, France: UNESCO Publishing.

UNAZA, 1971. Commission de Réforme de l'Enseignement Supérieur et Universitaire. Kinshasa: UNAZA.

Van der Walt, B.J. 2002. The Challenge of Christian Higher Education on the African Continent in the Twenty-First Century. Christian Higher Education 1(2-3): 195-227. Available from http://dx.doi.org/10.1080/15363750213811. Accessed on March 5, 2012.

VanZanten, S. 2011. Joining the Mission. A guide for (mainly) new college faculty. Grand Rapids, Michigan: Wm. B. Eerdmans Publishing Co.

World Bank. 2005. Education in the Democratic Republic of Congo. Priorities and Options for Regeneration. Washington, D.C.: The World Bank. 